\title{
NOVE KONCEPCIJE DRŽAVNE SUVERENOSTI I ORGANIZACIJE VLASTI U SRPANJSKIM USTAVNIM AMANDMANIMA IZ 1990. - UZ TRIDESETU GODIŠNJICU USTAVA RH
}

Sažetak: U godini u kojoj obilježavamo tri desetljeća od donošenja tzv. božićnog Ustava često se zanemaruje važnost ustavnih amandmana što ih je Sabor Republike Hrvatske proglasio krajem srpnja 1990., a koji u zajedništvu s onim veljačkim iz vremena još postojećeg socijalističkog Sabora čine temeljne pretpostavke inicijalne demokratizacije hrvatskoga ustavnog sustava. Autori s pravnopovijesnog $i$ ustavnopravnog motrišta razmatraju to važno pitanje moderne hrvatske države. Tradicionalna hrvatska historiografija ove amandmane analizira isključivo $u$ njihovu sadržajnom smislu reguliranja novog državnog grba, zastave i ukidanja socijalističkih atributa. Iako su amandmani normativno siromašni, njihovo je značenje ipak mnogo šire. U središtu ove analize pitanja su novog poimanja državne suverenosti $i$ reformskih zahvata u državnoj organizaciji. Autori raščlanjuju relevantne odredbe analizirajući ih $i$ kroz izvorne zapise saborskih rasprava. Prvo upućuju na osnovne trendove ustavnih promjena sadržanih $u$ srpanjskim amandmanima odnoseći se primarno na identitetsku razinu, a zatim ukazujemo na jačanje elemenata državnog suvereniteta te izmjene u smjeru razvoja obilježja modernih parlamentarnih demokracija. Tu se posebno razmatra predviđena reorganizacija izvršno-upravne vlasti. Na kraju se prikazuju odjeci srpanjskih ustavnih amandmana i početak rada na novom Ustavu $R H$.

Ključne riječi: $\quad$ srpanjski amandmani, veljački amandmani, državni suverenitet, privatno vlasništvo, Ustav SR Hrvatske, Ustav RH

\footnotetext{
* Dr. sc. Sanja Barić, redovita profesorica Pravnog fakulteta Sveučilišta u Rijeci, Hahlić 6, 51000 Rijeka. E-adresa: sbaric@pravri.hr. ORCID: https://orcid.org/0000-0001-6496-9062.

** Dr. sc. Budislav Vukas, ml., redoviti profesor Pravnog fakulteta Sveučilišta u Rijeci, Hahlić 6, 51000 Rijeka. E-adresa: bvukas@ pravri.hr. ORCID: https://orcid.org/0000-0003-0976-9169.
} 


\section{UVODNA PITANJA}

Godina 2020., osim zanimljiva u numerološkom smislu, te sasvim posebna po globalnim pandemijskim izazovima, godina je u kojoj "padaju” značajne obljetnice moderne hrvatske povijesti. Spominjemo se događaja koji će svojom važnošću bitno utjecati na procese izgradnje modernog hrvatskog ustavnog i državnopravnog sustava, s osnovnim imperativom dokidanja neuspješnih i propalih pokušaja izgradnje državnopravnih institucija kompatibilnih marksističkoj ideologiji i specifičnostima jugoslavenskog društvenog i državnog sustava. Ti su procesi u hrvatskom iskustvu bili vrlo kompleksni, uvjetovani i sasvim specifičnim i drukčijim zbivanjima u usporedbi sa srednjoeuropskim državama, pa i onima europskog jugoistoka.

Navedeni trendovi u Hrvatskoj otpočinju procesima demokratizacije ustavnog sustava stvorenog ustavnim okvirom iz 1974. godine. Ti su procesi, dakako, uvjetovani međunarodnim okolnostima i globalnim procesima, poglavito onim iz 1989. (poljski izbori, pad Berlinskog zida, neuspješnost dirigirane ekonomije i drugo), ${ }^{1}$ ali i izuzetno složenom državnom krizom, koja je od smrti Josipa Broza Tita 1980. sasvim otvoreno prijetila urušavanjem njezinih državnih institucija. Stoga je i sam hrvatski partijski vrh od svojih prosinačkih odluka 1989. ${ }^{2}$ stvarao pretpostavke te demokratizacije. Prvi korak goleme važnosti predstavljaju veljačke izmjene Ustava SR Hrvatske, ${ }^{3}$ koje su postavile ustavne i zakonske temelje za višestranačke izbore u Hrvatskoj. ${ }^{4}$ Kvalitetna i demokratska provedba izbora na zavidnoj razini političke kulture, uvažavajući relevantne demokratske i parlamentarne standarde, stvorit će pretpostavke za konstituiranje prvog višestranačkog saziva Hrvatskog sabora 30. svibnja 1990., s potpuno

1 Globalni su procesi u kontekstu raspada europskih komunističkih režima u zadnjoj dekadi 20. stoljeća - često teorijski identificirani kao "ustavni trenuci", pa i "ustavne revolucije" - općepoznato mjesto domaće ustavne literature i sastavnim su djelom osnovne udžbeničke misli. Vidi, primjerice Smerdel, B., Ustavno uređenje europske Hrvatske, Narodne novine, Zagreb, 2013., str. 46.-49.

2 Tog 10. prosinca 1989. Predsjedništvo CK-SKH donijelo je odluku o raspisivanju općih izbora na svim razinama na području Hrvatske. Ova će odluka bitno determinirati sve buduće događaje i odrediti ukupnost daljnjih političkih kretanja u Hrvatskoj. Značenje ove odluke, iako na prvi pogled logične, moramo sagledavati u suglasju sa svim okolnostima vremena, pri čemu se misli na nejasne konstelacije tadanjih međunarodnih odnosa, ali ponajviše na velikosrpski pokret koji je u sprezi s JNA, difamantno se zalažući za obranu Jugoslavije, sve agresivnije isticao svoje nacionalističke ciljeve. O glavnim pravnopovijesnim shemama i procesima raspada komunističkih sustava u državama srednje i jugoistočne Europe, s glavnim referencama na domaću i inozemnu literaturu vidjeti više u: Vukas, B., ml., Pravnopovijesne reference u ustavnim preambulama država srednje i jugoistočne Europe u postkomunističkom razdoblju, Zbornik Pravnog fakulteta u Zagrebu, vol. 63, br. 5 i 6, Zagreb, 2013., str. 1233.-1255., str. 1235. i dalje. Ovdje valja dodati i takve procese i aktere, koji neće imati pozitivan utjecaj na demokratizaciju u Hrvatskoj, napose djelovanje tajnih službi, ali i kontraobavještajnih struktura povezanih s velikosrpskom idejom i zapovjedničkim strukturama JNA.

3 Dana 14. veljače 1990. Sabor Socijalističke Republike Hrvatske prihvaća Odluku o proglašenju amandmana LIV. do LXIII. na Ustav Socijalističke Republike Hrvatske, Narodne novine, broj 7/1990. Ove ćemo amandmane više puta spominjati u radu, pa ćemo ih zvati veljački amandmani. Istog je dana usvojen Ustavni zakon za provođenje spomenutih amandmana, a narednog je dana, 15. veljače 1990., usvojen i dobro poznati "paket" pet izbornih zakona, svi objavljeni u Narodnim novinama, broj 7/1990.

4 Višestranački izbori, prvi nakon Drugog svjetskog rata, održani su uz primjenu apsolutno-većinskog izbornog sustava. Smerdel će, prisjećajući se tadašnjeg "ustavnog trenutka" navesti: "Autori izbornog zakona našli su se u situaciji koja je zahtijevala žurnu primjenu znanja iz područja 'ustavnog inženjeringa', sa zadaćom da u roku manjem od mjesec dana elaboriraju i pomognu provesti kroz ondašnji trodomni Sabor nužne ustavne promjene i izborni zakon. (...) Izabrali su izborni sustav koji je u danoj situaciji po njihovoj stručnoj spoznaji i procjeni jedini imao šansu da bude usvojen i primijenjen, te omogući miran prijenos vlasti.” Smerdel, B., Zadaće pravne znanosti i pravničke struke na dvadesetu obljetnicu „Božićnog ustava“ - ustavni izbor i procesi ostvarivanja najviših ustavnih vrednota i strateških ciljeva Republike Hrvatske, u: Dvadeseta obljetnica Ustava Republike Hrvatske (ur. Bačić, A.), HAZU, Zagreb, 2011., str. 41.-60., na str. 48.-49. O pogledu na ove izbore s politološkog motrišta vidi: Grdešić, I.; Kasapović, M.; Šiber, I.; Zakošek, N. (ur.), Hrvatska u izborima '90, Naprijed, Zagreb, 1991. O izbornim rezultatima i kasnijim odrednicama hrvatske politike i parlamentarizma vidi i: Kasapović, M. (ur.), Hrvatska politika 1990. - 2000 - izbori, stranke i parlament, Fakultet političkih znanosti, Zagreb, 2001. 
stabilnom i demokratskom procedurom tranzicije vlasti. ${ }^{5}$ Iako će na navedenoj sjednici biti najavljen rad na novom demokratskom ustavu, koji će postaviti temelje potpuno novog smjera ustavnog razvitka u Hrvatskoj, procesi najnužnije transformacije dotadašnjeg hrvatskog ustavnog sustava bit će okončani ustavnim amandmanima na Ustav SRH iz srpnja 1990. Ovi će amandmani dodatno pogurati tranzicijske procese i stabilizirati najosnovnije demokratiziran državni sustav, čime će biti olakšan put izgradnje hrvatskog ustavnog poretka izrastajućeg na najavljenom budućem novom Ustavu. Ti će amandmani iz srpnja 1990. godine predstavljati važan načelni korak, no ujedno i još jednu potvrdu da promjena, posebno fundamentalne naravi, u sferi ustavnosti, počiva na dugotrajnom procesu društvene transformacije i prihvaćanja novih uzusa. Drugim riječima, bilo je to raščišćavanje sa simbolima i nazivima, postulatima i paradigmama socijalizma. Raspao se okvir, kalup, no tijesto društvenog bića nije moguće preoblikovati u kratkom razdoblju.

Materiju razmatramo sljedećim redom: upućujemo na osnovne trendove ustavnih promjena sadržanih u srpanjskim amandmanima odnoseći se primarno na identitetsku razinu (2.), a zatim ukazujemo na jačanje elemenata državnog suvereniteta te izmjene u smjeru razvoja obilježja modernih parlamentarnih demokracija (3.). Ovdje valja i posebno razmotriti predviđenu reorganizaciju izvršno-upravne vlasti (4.). Na kraju prikazujemo odjeke srpanjskih ustavnih amandmana i početak rada na novom Ustavu RH (5.).

\section{OSNOVNI TRENDOVI USTAVNIH PROMJENA - SIMBOLIČKA I IDENTITETSKA RAZINA}

Novoizabrano hrvatsko državno vodstvo bilo je odlučno u donošenju novog ustava, ali svjesno da novi Ustav mora biti temeljito i sustavno osmišljen i pripremljen. Nepodijeljeno shvaćanje bilo je da je riječ o temeljnom zakonu praktički potpuno izmijenjenog državnog i društvenog sustava, koji će imati svoje zapadnoeuropske uzore, a to jasno naglašava kompleksnost predstojeće zadaće. Istovremeno, postupak promjene Ustava SRH, kojim se ovdje bavimo, odvio se vrlo brzo, a sve sukladno pozitivnim pravilima. Iako se u javnosti postavljalo pitanje zašto ići na ustavne promjene, kada je već zauzet stav o usvajanju novog Ustava, ustavni predlagatelj odlučio se za jednu normativno vrlo neopsežnu promjenu, koja je trebala naznačiti postupni proces preobrazbe i gašenja ideologijskih i koncepcijskih ustavnih temelja. ${ }^{6}$ Stoga je - svega dvadesetak dana nakon svojeg izbora - Predsjedništvo Republike, sukladno Ustavu SRH iz 1974. (članak 434. Ustava SRH), uputilo Saboru Prijedlog da se pristupi raspravi o promjeni Ustava SRH. U popratnom dopisu naznačeni su i temeljni pravci ustavnih promjena. ${ }^{7}$ Navedeni Prijedlog postao je sastavnim dijelom Odluke da se pristupi raspravi o promjeni

5 O samoj sjednici Hrvatskog sabora 30. svibnja 1990. vidi više u: Vukas, B., ml., Zasjedanje prvog višestranačkog hrvatskog sabora (30. svibanj 1990.) - početni impuls dugog putovanja Republike Hrvatske prema Europskoj uniji, u: Zbornik radova Bosna i Hercegovina i euroatlantske integracije - Trenutni izazovi i perspektive, Bihać, 7. i 8. svibnja, 2014., god. II., br. 2., tom I., str. 183.-218.

6 Usporediti govor potpredsjednika Sabora i predsjednika Komisije za ustavna pitanja Vladimira Šeksa na trećoj zajedničkoj sjednici svih triju domova Sabora 29. i 30. srpnja 1990., prema: Izvješća Hrvatskog sabora, br. 3, 9. VIII. 1990., str. 8.-9.

7 Predsjedništvo Socijalističke Republike Hrvatske Predsjedniku Sabora SRH, klasa 012-02/90-02/03, Ur. broj: 71201-90-1, od 21. lipnja 1990. 
Ustava SR Hrvatske, koju je prema svojim naznačenim ustavnim nadležnostima donio Sabor SR Hrvatske, na sjednici Vijeća udruženog rada, Vijeća općina i Društveno-političkog vijeća 29. lipnja 1990. godine. ${ }^{8}$ Ustavni postupak usvajanja amandmana bio je primarno reguliran Ustavom SR Hrvatske, pa je 30. lipnja donesena Odluka o stavljanju na javnu raspravu Nacrta amandmana LXIV. do LXXII. na Ustav SR Hrvatske. ${ }^{9}$ Već 25. srpnja sva tri vijeća Sabora prihvaćaju Nacrt i donose Odluku o proglašenju amandmana LXIV. do LXXV. na Ustav SR Hrvatske. ${ }^{10}$

Osnovni su razlozi i motivi ovih ustavnih izmjena, kao što je već spomenuto, bili simboličke i identitetske naravi. Zanimljivo je dometnuti kako Prijedlog nazivlje hrvatski Sabor "ustavotvornom i zakonodavnom skupštinom". Ovaj će Sabor u svakom pogledu biti ustavotvoran (poput Sabora iz 1947. ili nekih ranijih hrvatskih povijesnih "velikih" Sabora), ali i državotvoran jer će baš taj Sabor, koji će biti raspušten 1992., prihvatiti sve ključne ustavne, ali i državotvorne odluke o hrvatskoj samostalnosti i suverenosti. Ova primjedba može biti zanimljiva i u kontekstu nedavnih rasprava o državnim blagdanima te važnosti 30. svibnja 1990. za ukupnu hrvatsku povijest.

Osnovni atribut svih ustavnih promjena bila je deideologizacija ustavnog modela u onim sadržajima, koji prema stavu Predsjedništva, nisu mogli čekati najavljeni duži proces donošenja novog Ustava. ${ }^{11}$ Ta deideologizacija simbolički je najavljena uklanjanjem atributa "socijalistička" iz svih ustavnih stilizacija, uključujući i prijedlog naziva države-republike te samog Ustava. Drugi odraz tog ustavnog imperativa bio je vezan za novi državni grb i zastavu. Bio je to vrlo važan simbolički moment, promijeniti najvidljivije oznake prethodnog režima, a motiviran neprihvaćanjem dotadašnjih državnih simbola među većinskim dijelom građana. Tako je iz državne zastave uklonjena crvena zvijezda petokraka, a državni grb postao je povijesni grb s dvadeset i pet crvenih i bijelih polja. Tu je i odluka o popunjavanju ustavne praznine o službenom pismu u Republici, tj. navođenju latiničnog pisma kao službenog pisma u RH, te stvaranje uvjeta za ravnopravnu uporabu drugih manjinskih jezika i pisama (navodi se ćirilično) na onim hrvatskim područjima gdje je to određeno kao potrebno. Navedeni Prijedlog/Odluka ${ }^{12}$ označit će temeljne pravce srpanjskih ustavnih amandmana, s posebnim akcentom na nove koncepcije državne suverenosti, temeljne odredbe o koncepciji prava vlasništva i modelu organizacije vlasti. Ovi amandmani, zajedno s onim veljačkim, sadrže zanemarene, a važne odredbe vezane za poimanje ustroja i suodnosa tijela vrhovne državne vlasti i tijela nižih ustrojstvenih razina. One su još dakako na vrlo načelnoj razini, no pokazuju trendove ustavnopravnih i društvenih

$8 \quad$ Narodne novine, broj 28/1990.

9 Narodne novine, broj 28/1990.

10 Narodne novine, broj 31/1990.

11 Izradu novog Ustava najavio je Predsjednik Predsjedništva SRH na konstituirajućoj sjednici Hrvatskog sabora 30. svibnja 1990. u svojem inauguralnom govoru. Slično je naglasio i u uvodnom obrazloženju ustavnih amandmana u Saboru na zasjedanju Sabora 30. lipnja. Predsjednik Tuđman više je puta naznačio kako su amandmani tek put prema donošenju novog Ustava: "Sukladno tome, ustavne promjene što ih predlažemo sadašnjim amandmanima dalji su važan, koliko simbolički toliko i velik, korak prema našemu krajnjem ustavotvornom cilju - izradbi novog demokratskoga Ustava Republike Hrvatske. (...) Na putu prema tom demokratskom cilju, ovim amandmanima simbolički napuštamo institucije i označje ideološko-političke države, a usvajamo terminologiju i ustrojstvo pravne države. (...) Ove ustavne promjene moraju nam olakšati napore za oživotvorenje suvereniteta Hrvatske, i osigurati osnovne pretpostavke da najkasnije do kraja ove godine donesemo novi Ustav Republike Hrvatske." (govor predsjednika Tuđmana objavljen je u: Izvješća Hrvatskog sabora, br. 1, 5. VII. 1990., str. 2.).

12 Tekst Prijedloga Predsjedništva i Odluke Sabora u svojem su obrazloženju jednake, pa se u navođenju jednog izvora misli i na drugi i obrnuto. 
reformi tog povijesnog trenutka. S nekima od njih se, pokazat ćemo to kasnije, i danas, 30 godina poslije i pod božićnim Ustavom, i dalje nedovoljno kvalitetno suočavamo.

\section{NOVA KONCEPCIJA DRŽAVNE SUVERENOSTI I IZMJENE MEĐUODNOSA NAJVIŠIH DRŽAVNIH TIJELA U PRAVCU UTEMELJENJA PARLAMENTARNE DEMOKRACIJE}

Svakako najvažniji konceptualno-institucionalni pravci ustavne reforme bili su vezani za stvaranje temelja parlamentarno-demokratskog sustava vlasti, još nepotpuno razrađenog, ali uz jasnu najavu i uklanjanje modela jedinstva vlasti, ${ }^{13}$ koji je hrvatsku ustavnost obilježavao sve od koncepcija organizacije ZAVNOH-a i kasnijih ustavnih definiranja organizacije i nadležnosti Sabora. Kao pretpostavka navedenih trendova ustavni su amandmani trebali ojačati koncepciju hrvatske suverenosti. Stoga je u točki 3. Prijedloga/Odluke naznačeno: "Hrvatska državnost ima se temeljiti na jačanju i osiguranju punog suvereniteta hrvatskog naroda i neokrnjivih sloboda i građanskih prava svih državljana Hrvatske." ${ }^{14}$ Ojačavanje državne suverenosti postalo je sadržaj ustavnog amandmana LV. st. 1, koji navodi kako je "Republika Hrvatska nositelj političkog i gospodarskog suvereniteta”. Time je dopunjen čl. 1. Ustava, čije je značenje za hrvatsku povijest veliko. Člankom 1. Ustava, SR Hrvatska bila je, tako, prvi put u hrvatskoj povijesti definirana nacionalnom državom hrvatskog naroda, srpskog naroda i drugih naroda i građana koji u njoj žive. Ustavno ojačanje hrvatske suverenosti postat će polazište svih kasnijih prijedloga za rješavanje jugoslavenske krize jer će hrvatski argumenti uvijek polaziti od činjenice Republike Hrvatske kao suverene države. Ova će odluka biti dodatno ojačavana i u koncepciji novog Ustava RH, zakonskih intervencija iz prve polovine 1991., a svoje će konačno oblikovanje doživjeti u ustavnoj odluci prihvaćenoj 25. lipnja $1991 .{ }^{15}$ te onoj o prekidu svih državnopravnih sveza s jugoslavenskom državom i njezinim republikama od 8. listopada 1991. ${ }^{16}$ Hrvatski je suverenitet deklarativno međunarodno priznat 15. siječnja 1992., a u Domovinskom je ratu i obranjen.

Dodatno, osobito je važno bilo podcrtati i gospodarsku suverenost s obzirom na hrvatsku gospodarsku ulogu u tadašnjoj konjunkturi ekonomskih prilika u Jugoslaviji, ali i dominantne trendove ekonomskih politika jugoslavenske države u desetljećima njezina postojanja. Važan korak u pravcu oblikovanja hrvatske gospodarske suverenosti te promocije temeljnih građanskih prava, najavljenih u prijedlozima amandmana i samim amandmanima, bila je nova kon-

13 Tako će, primjerice, u temeljnoj hrvatskoj ustavnopravnoj udžbeničkoj literaturi sredine 80-ih godina 20. stoljeća biti navedeno: "Načelo demokratskog jedinstva vlasti prihvaća se u nas kao skup postavki o supremaciji skupštine unutar organizacije vlasti i samoupravljanja na razini društveno-političke zajednice čijom realizacijom valja spriječiti birokratizaciju i otuđenje izvršne funkcije od radničke klase i istovremeno osigurati radno samoupravno sudjelovanje što većeg broja radnih ljudi u odlučivanju o reguliranju društveno-ekonomskih i drugih društvenih odnosa koji su u nadležnosti skupštine. Za nas je stoga primarno u našim uvjetima nastojati da se skupština afirmira kao radno tijelo, a to se postepeno ostvaruje kroz delegatski skupštinski sistem." (S. Sokol) u Mratović, V.; Filipović, N.; Sokol, S., Ustavno pravo i političke institucije, Pravni fakultet u Zagrebu, Centar za stručno usavršavanje i suradnju s udruženim radom i Novinsko-izdavačka organizacija “Poslovna politika” Beograd, 1986., str. 397.

Točka 3. Prijedloga Predsjedništva SRH, str. 3.

Ustavna odluka o suverenosti i samostalnosti Republike Hrvatske te Deklaracija o uspostavi samostalne i suverene Republike Hrvatske, Narodne novine, broj 31/1991.

Odluka Hrvatskog sabora, Narodne novine, broj 53/1991. 
cepcija shvaćanja prava vlasništva, kao ključne pretpostavke izgradnje pravnog sustava, usklađenog sa zapadnoeuropskim standardima. Neuspjeli koncept društvenog vlasništva, koji je bio jedan od temelja jugoslavenskog pravnog sustava, trebalo je zamijeniti novim tradicionalnim oblicima vlasničko-pravnog uređenja. Obrazlažući navedene ustavne amandmane predsjednik saborske Ustavne komisije Vladimir Šeks, među ostalim je navodio: "Ustavne promjene koje se odnose na vlasništvo predstavljat će radikalan zaokret u gospodarskom životu u Republici. Republika će svojim zakonima ustanovljavati pojedine oblike vlasništva, s time da će svi oblici vlasništva biti ravnopravni i imati jednaku pravnu zaštitu. Ustav će jamčiti pravo vlasništva građana na poljoprivredno zemljište bez ikakvih ograničenja. Došlo je vrijeme da se društveno vlasništvo, svačije i ničije, pretvori u privatno vlasništvo i u druge oblike vlasništva, razumljivo, na način koji će biti propisan zakonom." ${ }^{17}$ Predlagatelj ustavnih amandmana polazi od principa tradicionalnog shvaćanja privatnog vlasništva, svjestan procesa pretvorbe društvenog vlasništva, jer je to pretpostavka uspješnog gospodarskog sustava.

Konkretizacija navedenog sadržaj je ustavnog amandmana LXVII. U svojem prvom općem članku propisuje: "Oblici vlasništva ustanovljuju se zakonom, ravnopravni su i imaju jednaku zaštitu. Nositelji prava vlasništva su fizičke i pravne osobe.” Drugi stavak jamči građanima pravo vlasništva na poljoprivredno zemljište, dok se treći stavak odnosi na mogućnost stjecanja prava vlasništva i stranim osobama. Članak 4. najavljuje procese pretvorbe društvenog vlasništva u privatno i drugo oblike vlasništva, koje će uvjete i način propisati zakon. Ove procese valja promatrati i u kontekstu saveznih i republičkih amandmana iz 1988., kojima su postavljeni svojevrsni temelji pravne afirmacije prava privatnog vlasništva. ${ }^{18}$ Detaljno razmatranje transformacije prava vlasništva nije predmet ovog istraživanja.

Vraćajući se na glavni predmet našeg istraživanja, svakako valja uočiti kako su trendovi uklanjanja modela jedinstva vlasti i stvaranja grubih osnova parlamentarno-demokratskog sustava poglavito vidljivi u veljačkim amandmanima, koje će oni srpanjski tek dopuniti. To se u prvom redu odnosi na definiranje osnova suodnosa izvršne i zakonodavne vlasti. Tako je amandman LXI. redefinirao ustavnu nadležnost Sabora u smislu izbora Izvršnog vijeća. Zbog uvođenja višestranačkog sustava Sabor bira predsjednika Izvršnog vijeća Sabora na prijedlog Predsjedništva Socijalističke Republike Hrvatske (čiji je izbor također u nadležnosti Sabora) tako da mandat povjeri osobi "za koju, na osnovi konzultacija i stranačkog rasporeda zastupnika smatra da uživa povjerenje većine zastupnika u Saboru.” Predsjednik Izvršnog vijeća predstavlja zatim svoj program svim saborskim vijećima (na zajedničkoj sjednici) te Saboru predlaže njegov sastav. Iako još nedefiniran ustavni model, ovaj je mehanizam regulacije odnosa zakonodavne i izvršne vlasti načelno prisutan u poredbenim zapadnoeuropskim parlamentarnim demokracijama u različitim modalitetima. Ustavni amandmani, naime, isključuju ustavne ovlasti koje je u imenovanju čelnih državnih dužnosnika dotad imao Socijalistički savez radnog naroda Hrvatske, kao ideološki najšira platforma predstavništva tzv. radnih ljudi, a ukinuto je i članstvo u vrhovnim tijelima Republike, koje su po funkciji imali dužnosnici SK (primjerice predsjednik Centralnog komiteta SKH i drugi). Navedeni ustavni amandman

17 Izvješća Hrvatskog sabora, br. 3, str. 9.

18 Vidi: Simonetti, P., Pravo na nekretninama, Pravni fakultet Sveučilišta u Rijeci, Rijeka, 2009., str. 3. i str. 22. Osobito vidjeti ustavni amandman XXIII iz 1988., čl. 1. i 2. Sistematizirajući razvitak hrvatske pravne povijesti u razdoblju od 1945. do 1990. Dalibor Čepulo fenomen društvenog vlasništva analizira kao formativnu odrednicu čitavog jugoslavenskog i hrvatskog državnopravnog sustava, Vidi, Čepulo, D., Hrvatska pravna povijest u europskom kontekstu - od srednjeg vijeka do suvremenog doba, Sveučilište u Zagrebu, Pravni fakultet, Zagreb, 2012., str. 314.-316. 
predviđa i situaciju neizbora predsjednika i članova Izvršnog vijeća, propisujući tek temeljne postupke i rok od šest mjeseci u kojemu predsjednik Sabora raspisuje nove izbore. Ova ustavna nadležnost predsjednika Sabora svakako je ostatak koncepta jedinstva vlasti jer su, kao što je dobro poznato, u načelu ovakve nadležnosti u parlamentarnim državama povjerene šefovima država. U okolnostima neizbora Izvršnog vijeća Predsjedništvo Republike je na dužnosti do izbora njegova novog saziva.

Afirmaciju koncepta podjele vlasti, simboličku ali nezanemarivu, vidimo i u tome što srpanjski amandmani ukidaju ideološke nazive vodećih tijela državne vlasti. Tako Sabor, sukladno amandmanu LXIV. mijenja naziv u Sabor Republike Hrvatske, dok je Izvršno vijeće, prema amandmanu LXXIII. postalo Vlada Republike Hrvatske. Ukida se i kolektivni šef države - Predsjedništvo. Njegov predsjednik je ustavnim amandmanom LXXI. sada Predsjednik Republike, dok su njegovi članovi potpredsjednici. Ova vrlo važna promjena dokida imperativ kolektivnih tijela državne vlasti, stvarana prema sovjetskom uzoru, uz specifičnosti jugoslavenskog ustavnog modela.

Srpanjski amandmani imaju iznimnu važnost i po još jednoj odluci. Nju je Prijedlog/Odluka naznačila sljedećom stilizacijom: "Ustav Republike Hrvatske ne bi smio sadržavati odredbe koje ukazuju na sumnju da bi Sabor mogao odlučivati suprotno interesima suvereniteta hrvatskog naroda ili protivno sloboda i prava svih građana Hrvatske. Građani Hrvatske, kada je riječ o zastupanju njihovih sloboda, prava i dužnosti u Saboru ne mogu se dijeliti po nacionalnoj, konfesionalnoj ili ma kojoj drugoj osnovi." ${ }^{19}$ Prijedlog dalje navodi kako "niti je politički opravdano, a niti ustavnopravno utemeljeno, da republički ustav sadrži posebne odredbe o načinu odlučivanja u Saboru kada je na dnevnom redu njegovih vijeća prijedlog akta ili drugo pitanje od interesa za ravnopravnost naroda i narodnosti. Stoga spomenute ustavne odredbe treba izostaviti iz republičkog ustava." Ovaj je zahtjev stiliziran u amandmanu LXVIII. na Ustav SRH, a odnosio se na veljački amandman LIX. koji je predviđao poseban mehanizam u zakonodavnom postupku u slučaju pozivanja na argument važnosti prijedloga akta za "ravnopravnost naroda i narodnosti” te, posljedično, u posebnom postupku, postavljanje obveznog zahtjeva da se takav akt treba izglasati dvotrećinskom većinom ukupnog broja zastupnika. ${ }^{20}$ Ova očita

19 Ovo se pitanje reaktualiziralo 2010. i 2011. godine, dakako, u drukčijem ustavnom okruženju božićnog Ustava, a tijekom njegove četvrte revizije (Promjena Ustava RH, Narodne novine, broj 76/2010) i usputnih izmjena Ustavnog zakona o pravima nacionalnih manjina (Ustavni zakon o izmjenama i dopunama Ustavnog zakona o pravima nacionalnih manjina, Narodne novine, broj 80/2010). Tim je izmjenama UZPNM-a bilo predviđeno uključivanje predstavljanja srpske nacionalne manjine $u$ okvire uporabe općeg biračkog prava na način da se predstavnici biraju s općih, a ne manjinskih lista, dok su ostale nacionalne manjine dobile dvostruko pravo glasa. Odlukom Ustavnog suda RH (Odluka U-I-3597/2010 i dr. od 29. srpnja 2011., Narodne novine, broj 93/2011) takva su rješenja ukinuta prihvaćanjem naše argumentacije, izrijekom citirane u Obrazloženju Odluke, a usporedive s u ovom radu navedenom stilizacijom Prijedloga/Odluke: "Svako izdvajanje bilo koje skupine hrvatskih državljana iz ukupnog korpusa 'naroda' po bilo kojem kriteriju, pa tako i kriteriju nacionalne pripadnosti, i kreiranje rješenja po kojem takva skupina biva posebno predstavljena primjenom općeg i jednakog biračkog prava smatram ustavnopravno neprihvatljivim, odnosno suprotnim temeljnom slovu i smislu Ustava RH, samom temeljnom pojmu 'naroda' 'iz kojeg proizlazi vlast i kome pripada vlast'. Takvo rješenje presumira da postoje različiti, ustavnopravno priznati i prepoznati dijelovi naroda, što se ima reflektirati u zastupljenosti pojedinih dijelova općeg i zajedničkog pojma naroda. To nije slučaj s Ustavom RH. Narod je jedan i jedinstven i u ustavnopravnom smislu čine ga svi državljani RH, bez obzira na njihove osobne karakteristike, pa tako i nacionalnu pripadnost." (iz stručnog mišljenja Barić, S., Obrazloženje, t. 31.).

20 Taj je postupak bio u nadležnosti veljačkim amandmanima novoosnovane Komisije za zaštitu i unapređenje ravnopravnosti naroda i narodnosti, a koja je zamijenila slično tijelo prema članku 380. Ustava SRH. Nadležnost ranijeg tijela, kojem je po funkciji predsjedavao predsjednik Sabora, bila je načelno vezana za praćenje ostvarivanja nacionalnih prava i moguće usvajanje mjera za njihovo poboljšanje ili očuvanje (u članku 380. navodili su se pojedinačno Hrvati i Srbi i drugi narodi i narodnosti - taj članak nije izbrisan veljačkim amandmanom). Istovjetni postupak moglo je pokrenuti desetero zastupnika. Za prihvaćanje takvog akta u tom se slučaju tražila dvotrećinska većina svih zastupnika. Ustavna komisija Sabora branila je stav kako se izmjenom ovih amandmana ničim ne ukidaju načela "ravnopravnosti naroda i narodnosti". Drugi je argument bio kako je ovaj mehanizam tek 
manipulacija bila je razmatrana kao moguća pravna blokada i za usvajanje ustavnih amandmana o kojima raspravljamo, no potpredsjednik Sabora i predsjednik saborske Komisije za ustavna pitanja, Vladimir Šeks, argumentirano je pravno osporio ovu opasnost, tumačeći da se navedeni (veljački) amandman odnosi isključivo na promjenu zakona. U svakom slučaju ovu je odredbu trebalo ukloniti iz tadašnjeg ustavnog prava SR Hrvatske. ${ }^{21}$ Prikazani mehanizam značio je i bitno odstupanje od klasičnog modela parlamentarnog odlučivanja u okvirima suverenog i demokratskog parlamenta, svojevrsno "parainstitucionalno tijelo"22 unutar Sabora. Inzistiranje na njegovu uklanjanju bilo je, s jedne strane pragmatično (da ne bi blokiralo donošenje novih ustavnih amandmana), ali je imalo i šire značenje, u smislu jačanja demokratskih trendova i uloge tradicionalnog parlamenta, bliže europskoj praksi. Navedeno je i izmijenjeno i čini amandman LXVIII. st. 2. Ukinuta je mogućnost da deset saborskih zastupnika inicira ovakav prijedlog, a izmijenjena je i većina, koja sada (nakon srpanjskih amandmana) više nije dvotrećinska većina svih zastupnika, već samo većina prisutnih zastupnika (relativna većina).

Pogledajmo još i opsežni amandman LXXIV. u dijelu koji se odnosi na izmjene nadležnosti Sabora. On slijedi temeljni stav ukidanja sustava samoupravnih interesnih zajednica; tim amandmanom Sabor prestaje biti ideološki entitet u sustavu udruženog rada, gdje je on imao određena prava suodlučivanja ili koordiniranja svojih odluka sa skupštinama samoupravnih interesnih zajednica. Vrlo opsežan ustavni članak 364., ${ }^{23}$ ali i neki amandmani prihvaćeni u vremenu socijalističke vlasti, ovim su amandmanom bitno izmijenjeni, učvršćujući ulogu Sabora kao zakonodavnog tijela, a sustav samoupravnih interesnih zajednica povezujući s klasičnim upravnim sustavom.

Bili su to tek nužni zahvati sanacije ruševina goleme ideološke pravne arhitekture, koja je potpuno nestajala. Valja prikazati kako se i u vertikalnom dijelu međuodnosa ocrtavaju novi trendovi organizacije nižih razina vlasti, bitan element modernih ustavnih država, čije zadovoljavajuće funkcioniranje ni do danas nije u potpunost ostvareno.

\section{NOVI TRENDOVI U ORGANIZACIJI IZVRŠNO-UPRAVNE VLASTI}

Sukladno promociji novih liberalno-demokratskih načela napuštanja načela jedinstva vlasti, već su dosad obrazloženi prijedlozi ustavnih amandmana polazili od ukidanja kolektivnih tijela, šefova države ili čelništva parlamenta. Stoga je već Prijedlog Predsjedništva, respektirajući republikansko načelo vlasti, predlagao uvođenje institucije Predsjednika Republike, dok bi, vjerojatno privremeno, članovi Predsjedništva postali njegovim potpredsjednicima. ${ }^{24} \mathrm{Uz}$

možebitni lex specialis u odnosu na postupak donošenja akta, a osnovno pravilo izmjene Ustava SRH njegov je članak 386., koji predviđa većinu prisutnih zastupnika.

21 Iz točke 4. Prijedloga/Odluke. Vidjeti obrazloženje Vladimira Šeksa na sjednici Sabora, prema: Izvješća Hrvatskog sabora, br. 1, 5. VII. 1990. str. 8.-9.

22 Tako A. Bačić, u drugom kontekstu, u Bačić, A. i Bačić, P., Legislature i parlamentarizam, Pravni fakultet u Splitu, Split, 2007., str. 19.

23 Vidi članak 364. Ustava SR Hrvatske, Narodne novine, broj 8/1974.

24 U ovom kontekstu valja napomenuti kako je ovo vrlo demokratski potez nove vlasti s obzirom na to da su među članovima Predsjedništva bili imenovani i oporbeni političari tadašnjeg SKH-SDP-a. Članovi Predsjedništva SHR su uz predsjednika Tuđmana bili Krešimir Balenović, Dušan Bilandžić, Dalibor Brozović, Josip Manolić, Anton Vrdoljak i Milojko Vučković. 
Predsjednika Republike umjesto Izvršnog vijeća Sabora, amandmani na čelu izvršno-upravne vlasti postavljaju Vladu Republike Hrvatske, dok su republički sekretarijati postali ministarstvima, a njihovi čelnici ministri. Time je najavljeno dokidanje načela jedinstva vlasti i u smjeru diferenciranja izvršne vlasti, i smjeru njezine odgovornost prema zakonodavnoj vlasti Sabora. ${ }^{25}$

Već je Prijedlog Predsjedništva detektirao da je izvršavanje zakona i drugih propisa i općih akata jedna od najslabijih točaka pravnog sustava u Hrvatskoj. Naglašeno je kako "republički ustav ne sadrži dovoljno djelotvornih rješenja za otklanjanje spomenutih poteškoća u funkcioniranju pravnog sustava. Zbog toga bi bilo potrebno stvoriti ustavni temelj za donošenje republičkog zakona kojim će se utvrditi prava i dužnosti Sabora RH, Vlade Republike Hrvatske i nadležnih republičkih organa uprave na poduzimanje mjera prema skupštinama užih društveno-političkih zajednica, njihovim izvršnim vijećima odnosno organima uprave u slučajevima kada ti organi ne izvršavaju odnosno ne osiguravaju izvršavanje zakona, drugih propisa i općih akata." 26 Spominje se i pravo davanja općih instrukcija nižim lokalnim tijelima uprave. Pretpostavka navedenog svakako je bila dodatna deideologizacija ustavnog sustava, napose u smislu odmicanja od koncepcije udruženog rada i samoupravnih interesnih zajednica, te stvaranja jasnijih odnosa u pitanjima nadležnosti i odnosa između tijela državne uprave i lokalne samouprave.

Ti su zahtjevi Prijedloga/Odluke ugrađeni u ustavne amandmane i čine jedan od njihovih zanimljivih sadržaja. Amandmani ukidaju mogućnost stvaranja zajednica općina ili njihova udruživanja, smatrajući ih financijski opterećujućim za građane. ${ }^{27}$ Nova koncepcija stvaranja upravnog uređenja Republike Hrvatske prepuštena je novom Ustavu, a ona mora slijediti zapadnoeuropske modele.

Jačanje načela podjele vlasti i afirmacija izvršno-upravnog sustava, koji je kompromitirala praksa neprovedbe zakona, svakako je trebalo osigurati i prije donošenja novog Ustava. Na takve pojave osobito je ukazao u predlaganju amandmana predsjednik saborske Ustavne komisije, Vladimir Šeks, kada je navodio: "U Ustav se predlaže ugraditi mehanizam kojemu je cilj osigurati izvršavanje zakona na cijelom području Republike i odstraniti zatvaranje užih društveno-političkih zajednica u feude bezakonja. Tim se novim ustavnim rješenjima predlaže pravo i obveza Sabora, Vlade i republičkih ministarstava da - razumljivo, u skladu s Ustavom i zakonom - poduzimaju mjere prema organima užih društveno-političkih zajednica u slučaju da ne izvršavaju, odnosno ne osiguravaju izvršenje zakona. Takvim mehanizmima raspolažu sve suvremene i efikasne države. Time se lokalna samouprava ne negira, već dapače afirmira." 28 Sljedeći je trend u demokratizaciji državne uprave i povećanju njezine učinkovitosti svakako bio vezan za već spomenuto ukidanje samoupravnih interesnih zajednica. Njihove poslove trebale su preuzeti institucije upravnih tijela, ustanove ili trgovačka društva. Sve su to sadržaji amandmana LXVIII. i LXXIV. Ovim vrlo sažetim amandmanima postavljeni su tek grubi temelji stvaranja modernog upravnog sustava i društvenih odnosa sukladnih demokratskim

25 Valja napomenuti kako je načelo jedinstva vlasti, koje je postojalo u državama socijalističkog tipa, u mnogim državama imalo poremećaje prema dominaciji izvršne vlasti. O tome više: Čepulo, D., op. cit. u bilj. 18, str. 312.-314.

26 Točka 6. Prijedloga/Odluke.

27 Ovo je sadržaj amandmana LXXIV., a zajednice općina ukinute su člankom 3. Ustavnoga zakona za provedbu amandmana LXIV. do LXXIV. na Ustav Socijalističke Republike Hrvatske, Narodne novine, broj 31/1990. 
standardima. Ipak, njima su neuspješni i nerazumljivi, hipernormirani i hipertrofirani mehanizmi, kojima je trebalo ostvariti tzv. samoupravna načela u raznim društvenim odnosima i interesima, u potpunosti dokinuti.

Ustavni amandman LXXIV. u svojem prvom općem članku glasi: “Za ostvarivanje Ustavom i zakonom zajamčenih prava i utvrđenih potreba i interesa društva u oblastima odgoja i obrazovanja, znanosti, kulture, zdravstva, socijalne zaštite, mirovinskog i invalidskog osiguranja, socijalne sigurnosti, tjelesne kulture, tehničke kulture, društvene brige o djeci, vodoprivrede, stambenoj i komunalnoj i drugim oblastima utvrđenim zakonom sredstva se osiguravaju budžetom društveno-političke zajednice, u društvenom fondu ili na drugi zakonom utvrđen način. Građani imaju pravo slobodno se organizirati i ustrojavati odgovarajuće institucije, radi zadovoljavanja svojih osobnih i zajedničkih potreba u tim oblastima." Posebni stavci ovog amandmana ukidaju one ustavne članke koji su navedene nadležnosti organizirali sukladno neuspješnom sustavu samoupravnih interesnih zajednica.

Ovaj vrlo složeni problem, jasno je, amandmani su tek načelno regulirali, ostavivši novom Ustavu stvaranje potpuno novog sustavnog koncepta uređenja središnje državne uprave, lokalne uprave i samouprave. Slijedit će i opsežna teritorijalno-upravna reorganizacija, a pitanje upravnog uređenja države, i unatoč kontinuiranim reformama, ostaje aktualno i prijeporno do danas. ${ }^{29}$

\section{ODJECI USTAVNIH AMANDMANA}

Složenost i slojevitost jugoslavenske krize bili su razlozima najrazličitijih odjeka ustavnih amandmana, kako u parlamentarnoj raspravi, tako i u tadašnjoj javnosti te hrvatskoj historiografiji i pravnoj doktrini. Promjena državnih simbola i uvođenje latiničnog pisma kao službenog u RH u vrijeme donošenja srpanjskih amandmana izazivali su velik javni interes, dok su nova demokratska pravna načela i opće spoznaje o neuspješnosti socijalističkih modela u okolnostima sloma tog sustava bila manje interesantna i kritizirana.

Percepcija amandmanima iz hrvatske nacionalne perspektive, koju je ponajviše predstavljao vladajući HDZ i još neke manje stranke iz redova Koalicije narodnog sporazuma, ali i neki pogledi iz redova reformiranih komunista (SKH-SDP) i osobito socijaldemokrata (SSDH), pozdravljali su amandmane, napose one vezane za jačanje državne suverenosti, promjene nacionalnih simbola ili definiranja latiničnog pisma službenim pismom u RH. Tim je samo ojačana suverenost i nastavljen proces oblikovanja republike-države, o čijoj se budućnosti promišljalo

29 S donekle sličnom artikulacijom problema učinkovitosti sustava lokalne samouprave nosimo se i danas, 30 godina nakon donošenja božićnog Ustava. Vidi npr. intervju u Večernjem listu, prilog OBZOR od 25. travnja 2020., prof. I. Koprić: "Novi model kojeg predlažem osigurao bi bolji razvoj, solidarnost i očuvanje naseljenosti u manjim sredinama, jednake usluge za svakoga ma gdje živio, bolju transparentnost trošenja lokalnog novca i bolji nadzor. Možda je za spomenuti da je 576 lokalnih jedinica osnovalo skoro 8000 dodatnih pravnih osoba, lokalnih agencija, trgovačkih društava, ustanova i mjesnih odbora. Zato sustav lokalne samouprave nema 576, nego oko 8300 pravnih osoba s njihovim zasebnim prihodima, rashodima i žiro-računima. Zato je percepcija korupcije na lokalnoj razini visoka jer građani osjete to 'kretanje novca'. Mjere transparentne objave troškova i zaduživanja svih lokalnih tijela i njihovih pravnih osoba na njihovim web stranicama ključni su dio reforme."

Ili Bohutinski, J., Novi ustroj Hrvatske: treba nam 5 regija i 100 gradova i općina, u: Večernji list, https://www. vecernji.hr/vijesti/ novi-ustroj-hrvatske-treba-nam-pet-regija-i-100-gradova-i-opcina-1399506, 4. svibnja 2020. Pristupljeno 5. svibnja 2020. 
kao suverenoj državi, koja će kao takva ravnopravno s drugima regulirati sve buduće državnopravne ili međunarodnopravne odnose..$^{30}$

Druga je percepcija amandmana bila vezana za jugoslavensku perspektivu, još i dalje dijelom u ideološkim okvirima. Neki su protagonisti, dionici tih pogleda, naglo evoluirali u pravcu naglašenog zalaganja za liberalno-demokratske vrijednosti, potpuno suprotne vrijednosnim sustavima čijim su promotorima bili tek nekoliko mjeseci prije. Tu su dakako i pobornici jugoslavenskih krugova koji su se oduvijek zalagali za liberalne ili liberalnije vrijednosti, no nisu bili predvodnici nekog programa oblikovanja hrvatske države ili jače individualizacije hrvatskih nacionalnih vrijednosti. U taj kontekst spadaju i pobornici novoosnovanih regionalističkih stranaka, čiji su osnivački programi još pomalo nejasni i kontradiktorni. Neki su se iz tih krugova u saborskoj raspravi osobito zalagali za primjenu veljačkog amandmana LIX., a nipošto za mogućnost njegove izmjene. ${ }^{31}$ Paradigma "ravnopravnosti naroda i narodnosti" i slične nekadašnje jugoslavenske parole, bili su dijelom vrijednosnog sustava, kojeg su u novim demokratskim imperativima nastojali očuvati. Dakako, ta perspektiva nije uočavala činjenicu kako je srpsko stanovništvo u Hrvatskoj tada brojilo tek oko $12 \%$, a njegov gotovo privilegiran položaj u Hrvatskoj svakako nije zahtijevao navedena ustavna načela ili mehanizme koje je predstavljao veljački amandman. Stoga zastupnici poglavito SKH-SDP-a iz razloga zalaganja za navedena ustavna načela nisu podržali neke amandmane. ${ }^{32}$

Potpuno negiranje ovakvih amandmana svakako je dolazilo iz redova postojeće i već jasno oblikovane i organizirane velikosrpske koncepcije. Inspirirana Memorandumom SANU, ovakva koncepcije nije prihvaćala nikakvu mogućnost jačanja hrvatske suverenosti, a oblikovanje njezina individualiteta i državnosti ona je poistovjećivala s režimom koji je na hrvatskom prostoru postojao u vremenu Drugog svjetskog rata. Stoga je na isti dan, kada su prihvaćeni amandmani na Ustav u Srbu organiziran veliki miting koji su organizatori nazivali "Sabor srpskog naroda”. Tamošnji govornici zastupali su zlokobnu Miloševićevu tezu, suprotno slovu Ustava SFRJ, kako su suvereni narodi, a ne republike, a što je predstavljalo jednu od sržnih idejnih točaka velikosrpske koncepcije. Ti narodi se, navodno, mogu odvajati, nevezano za sustav republičkih granica. ${ }^{33}$ To su bili sadržaji čak i mitingaških deklaracija. Sve je navedeno

30 Saborska rasprava o amandmanima svodila se ponajviše na osmišljavanje novog hrvatskog grba, ideje o oblikovanju zastave, pozdravljanje načela suverenosti i ustavnopravnog definiranja latiničnog pisma. Vidi: Sjednica saborskih vijeća 25. i 26. srpnja 1990., u: Izvješća Hrvatskog sabora, br. 2, 9. VIII. 1990., str. 10.-21.

31 Tako je na temelju amandmana LIX. na Ustav SRH i članak 248. Ustava SRH i saborskog Poslovnika grupa zastupnika iz sva tri vijeća Sabora podnijela Zahtjev za provođenje posebnog postupka kojim se traži da vijeća odlučuju dvotrećinskom većinom ukupnog broja svih članova pri odlučivanju o aktu Prijedloga amandmana na Ustav SR Hrvatske. Vidi: Izvješća Hrvatskog sabora, br. 2, 9. VIII. 1990., str. 13.

32 Razmatrajući novi grb i zastavu, neki su pobornici ovih grupacija tumačili kako je povijesni hrvatski grb činio sastavni dio grba opisanog Ustavom SRH. Neki zastupnici iz Istre držali su kako njezin identitet nije vidljiv u takvom grbu. Bilo je i različitih novih ideja o zastavi, pa i onih kako je crvena zvijezda simbol oslobođenja i stvaranja moderne Hrvatske. Od drugih gledišta, koje možemo staviti u pobornike trenda kako smo diferencirali, neki su zastupnici hrvatski suverenitet isključivo vezivali uz postojeću jugoslavensku državnu zajednicu, a njezinu su optimalnu budućnost vidjeli u okvirima europskih integracija. Bilo je i kritika na nov koncept mjera za nadzor djelovanja upravnih i samoupravnih tijela vlasti, s argumentacijom kako su suprotne Ustavu, koji zastupa skupštinsko komunalno načelo i nije prilagođeno modelu podjele vlasti. Zastupnici su se često pozivali i na odluke ZAVNOH-a i njihovu koncepciju regulacije međunacionalnih odnosa. Zanimljivo je kako su u raspravi sudjelovali i neki zastupnici srpske nacionalne zajednice, čija se argumentacija, različita od one vladajuće stranke, nikako ne može poistovjetiti s bilo kakvim velikosrpskim konceptom. Sve prema: Sjednica saborskih vijeća 25. i 26. srpnja 1990., u Izvješća Hrvatskoga sabora, br. 3, 9. VIII. 1990., str. 17.-21.

33 Ova će teza biti osporena i Mišljenjima Badinterove komisije prihvaćanjem međunarodnopravnog načela uti possidetis iuris. O tome, Vukas, B., ml., Hrvatska državnost - pravnopovijesne prosudbe, Pravni fakultet Sveučilišta u Rijeci, Rijeka, 2017., str. 172.183. Vidi i Crnić-Grotić, V., Načelo uti possidetis u međunarodnom pravu, Zbornik Pravnog fakulteta Sveučilišta u Rijeci, vol. 16, 
najavljivao planirane aktivnosti destabilizacije $\mathrm{RH}$, koje će za tek nekoliko tjedana prerasti u terorističke aktivnosti, a onda i u oružanu agresiju protiv $\mathrm{RH}$. Uz beogradske inspiratore na mitingu su sudjelovali i predstavnici manjih ekstremnih stranaka srbijanske političke scene, poput kasnijeg optuženika za teške međunarodne ratne zločine Vojislava Šešelja. ${ }^{34}$

Razmatrani amandmani ostali su u hrvatskoj nacionalnoj memoriji najpoznatiji prema promjeni državnih simbola jer su za povijest ostali nezaboravni trenutci svečanog skidanja hrvatske zastave s crvenom zvijezdom sa zgrade Sabora i podizanje nove povijesne hrvatske zastave s grbom, popraćene spontanom narodnom svečanošću i emotivnom reakcijom predsjednika Republike. Stoga su u hrvatskoj historiografiji najpoznatiji prema tom simboličkom činu. Tako primjerice Nevio Šetić ustavnim amandmanima i donošenju novog Ustava RH posvećuje jedno kraće poglavlje u svojoj sintezi "ostvarenja suvremene hrvatske države”. To poglavlje novi naslov "Korekcije Ustava SR Hrvatske i donošenje Ustava Republike Hrvatske”. Rabeći izraz "korekcije", Šetić svakako misli na korekcije Ustava u pravcu njegove demokratizacije i deideologizacije. On vrlo jasno i sumarno prikazuje amandmane, a opisujući čin skidanja zastave piše: "Građani, koji su se u tom trenutku tu našli, kao i više saborskih zastupnika i dužnosnika, srdačnim su pljeskom pozdravili tu smjenu. Bilo je u toj smjeni zastave i simbolike i stvarnog društveno-političkog razmeđa. Spuštanje zastave SRH značilo je definitivno preminuće hrvatskog socijalističkog sustava, a s njime i zaključenje jednog svršenog vremena, koje postaje prošlost. Podizanje zastave RH značilo je oznanjenje rođenja jednog novog društvenog poretka, a s njime i nastajanje jednog novog doba, otvorenog sadržajima daljnjeg životnog hoda u skladu s kretanjima u ostalom, slobodnom i demokratskom svijetu." ${ }^{5}$ Od historiografskih radova možemo navesti i onaj Ive Goldsteina, koji u svojem radu zahvaćajući dulje razdoblje dominantno akcentuira društvenu atmosferu i različite refleksije nastupanja nove vlasti. ${ }^{36}$ I drugi povijesni radovi sadrže sličan pristup. Amandmani su katkad i citirani u izdanjima pravnih i povijesnih izvora. Tako veljačke amandmane citira Nevio Šetić u dijelu navedene knjige koji posvećuje izvorima, a već 1992. Anđelko Milardović im daje nesporno mjesto u svojoj publikaciji "Dokumenti o državnosti Republike Hrvatske". ${ }^{37}$ Vrlo se često u suvremenim povijesnim djelima i radovima ovi amandmani i sagledavaju u kontekstu koraka k donošenju novog Ustava. To je i logično, budući da je na istoj sjednici Sabora predsjednik Tuđman predstavio metodološke polazne osnove za izradu novog Ustava, a Sabor je usvojio i odluke koje otpočinju postupak pripreme novog Ustava.

Bez potrebe normativne analize dotadašnjeg Ustava SR Hrvatske, kao i uostalom onog šire federativne zajednice Jugoslavije, posve je razvidno kako su ti ustavni tekstovi dotad već u tolikoj mjeri bili nekoherentni i nerazumljivi te nikakve daljnje izmjene i dopune nisu mogle postići željeni cilj: stvaranje temeljnog pravnog okvira za demokratski razvoj Hrvatske. Daljnja

1995., str. 295.-308. ili Seršić, M., Načelo “uti possidetis" u međunarodnom pravu, Zbornik Pravnog fakulteta u Zagrebu, vol. 53, br. 2, 2003., str. 309.-324.

Prema emisiji TV kalendar Hrvatske radiotelevizije, 25. srpnja 2014. https://www.youtube.com/watch?v=cn9MY2HNJwo. Pristupljeno 20. ožujka 2020. Usporedi: Bilandžić, D., Hrvatska moderna povijest, Golden marketing, Zagreb, 1999., str. 736.779. i Brandt, M.; Čović, B.; Letica, S.; Pavić, R. et al., Izvori velikosrpske agresije, August Cesarec, Zagreb, 1991. Vidi više: Barić, N., Srpska pobuna u Hrvatskoj, Golden marketing - Tehnička knjiga, Zagreb, 2005.

35 Šetić, N., Ostvarenje suvremene hrvatske države - od pojave višestranačja 1989. do nastanka samostalne i međunarodno priznate, teritorijalno cjelovite Republike Hrvatske, Družba “Braće hrvatskoga zmaja”, Drugo izdanje, Zagreb, 2017., str. 186. 
zbivanja odvijala su se gotovo munjevito, "gonjena visokom motivacijom i suglasnošću sudionika”, ${ }^{8}$ a prvi je predložak novog Ustava, tzv. Krčki nacrt, bio dovršen već krajem kolovoza 1990. godine. Detalji narednih zbivanja dobro su poznati, ${ }^{39}$ a kulminacija stiže svečanim proglašenjem novog Ustava RH, 22. prosinca 1990. godine.

\section{ZAKLJUČNE NAPOMENE}

U kontekstu procesa demokratizacije hrvatskog ustavnog i pravnog sustava, otpočetog općim zbivanjima u istočnoj Europi, srpanjski amandmani, iako normativno ne odveć opsežni, ipak imaju svoju važnost za hrvatsku pravnu povijesti i ustavni razvitak. Oni okončavaju demokratizaciju ustavnog modela prethodnog sustava, a u zajedništvu s veljačkim amandmanima, najavljuju opću ustavnu reformu. Ovi amandmani dakako upućuju tek na osnovne pravce daljnje izgradnje hrvatskog pravnog sustava, stvaraju preduvjete građansko-demokratskog društva, slobodnog poduzetništva i jasno poručuju da je prethodni socijalistički sustav potrošen, prevladan i odbačen. S gledišta hrvatske državnosti i njezina položaja u jugoslavenskoj državi, njihova je važnost znatna jer su dodatno ojačali i definirali Hrvatsku kao suverenu državu, a time je i većinska volja hrvatskoga naroda izražena na prvim višestranačkim izborima bila ustavnopravno regulirana. U pogledu institucionalnog sustava Republike Hrvatske ovi su amandmani, kao i oni veljački, tek otvorili mogućnost njegove demokratizacije te simbolički postavili temelje budućeg demokratskog oblikovanja i djelovanja. Institucionalna struktura istinske ustavne demokracije bit će uspostavljena tek božićnim Ustavom, a potom i dograđivana u kasnijim desetljećima.

Hrvatska iskustva procesa "ustavnih revolucija" posebna su u usporedbi s iskustvima drugih istočno-europskih država i, nažalost, nisu mogla spriječiti ratna zbivanja i zadržati samo metaforičko značenje imenice u ovoj sintagmi. Kompleksnost jugoslavenske krize, izravne prijetnje jugoslavenske vojske i čitave mreže najrazličitijih sigurnosnih čimbenika, građenih desetljećima, svakako su uvjetovale i posebnosti djelovanja nove hrvatske vlasti. Njezina demokratska ideja rezultirat će opsežnim nastojanjima čiji će uspjeh biti vidljiv u božićnom Ustavu, a srpanjski amandmani svakako ostaju važni i hrabri iskoraci u tom smjeru, primjereni vremenu i povijesnom trenutku.

\section{LITERATURA}

1. Bačić, A. i Bačić, P., Legislature i parlamentarizam, Pravni fakultet u Splitu, Split, 2007.

2. Barić, N., Srpska pobuna u Hrvatskoj, Golden marketing - Tehnička knjiga, Zagreb, 2005.

3. Bilandžić, D., Hrvatska moderna povijest, Golden marketing, Zagreb, 1999.

38 U spomen na ta zbivanja tiskana je knjižica izlaganja s okruglog stola održanog u povodu 25. obljetnice donošenja prvog hrvatskog Ustava čiji je Nacrt, izrađen u kolovozu 1990. u Malinskoj na otoku Krku, prozvan "Krčkim ustavom" (Malinska, 27. kolovoza 1990.). Galović, T. (ur.), Hrvatski ustav i njegov "Krčki nacrt” (1990.), Povijesno društvo otoka Krka, Krk - Malinska, 2018. Navedeni citat je iz Predgovora B. Smerdela, str. 14. 
4. Brandt, M.; Čović, B.; Letica, S.; Pavić, R. et al., Izvori velikosrpske agresije, August Cesarec, Zagreb, 1991.

5. Crnić-Grotić,V., Načelo uti possidetis u međunarodnom pravu, Zbornik Pravnog fakulteta Sveučilišta u Rijeci, vol. 16, 1995., str. 295.-308.

6. Čepulo, D., Hrvatska pravna povijest u europskom kontekstu - od srednjeg vijeka do suvremenog doba, Sveučilište u Zagrebu, Pravni fakultet, Zagreb, 2012.

7. Galović, T. (ur.), Hrvatski ustav i njegov "Krčki nacrt" (1990.), Povijesno društvo otoka Krka, Krk-Malinska, 2018.

8. Goldstein, I., Dvadeset godina samostalne Hrvatske, Novi Liber, Zagreb, 2010.

9. Grdešić, I.; Kasapović, M.; Šiber, I.; Zakošek, N. (ur.), Hrvatska u izborima '90, Naprijed, Zagreb, 1991.

10. Kasapović, M. (ur.), Hrvatska politika 1990. - 2000 - izbori, stranke i parlament, Fakultet političkih znanosti, Zagreb, 2001.

11. Milardović, A., Dokumenti o državnosti Republike Hrvatske, Alinea, Zagreb, 1992.

12. Mratović, V.; Filipović, N.; Sokol, S., Ustavno pravo i političke institucije, Pravni fakultet u Zagrebu, Centar za stručno usavršavanje i suradnju s udruženim radom i Novinsko-izdavačka organizacija "Poslovna politika" Beograd, 1986.

13. Seršić, M., Načelo "uti possidetis" u međunarodnom pravu, Zbornik Pravnog fakulteta u Zagrebu, vol. 53, br. 2, 2003., str. 309.-324.

14. Simonetti, P., Pravo na nekretninama, Pravni fakultet Sveučilišta u Rijeci, Rijeka, 2009.

15. Smerdel, B., Ustavno uređenje europske Hrvatske, Narodne novine, Zagreb, 2013.

16. Smerdel, B., Zadaće pravne znanosti i pravničke struke na dvadesetu obljetnicu "Božićnog ustava" - ustavni izbor i procesi ostvarivanja najviših ustavnih vrednota i strateških ciljeva Republike Hrvatske, u: Dvadeseta obljetnica Ustava Republike Hrvatske (ur. Bačić, A.), HAZU, Zagreb, 2011., str. 41.-60.

17. Šarin, D., Nastanak hrvatskoga Ustava, Narodne novine, Zagreb, 1997.

18. Šetić, N., Ostvarenje suvremene hrvatske države - od pojave višestranačja 1989. do nastanka samostalne i međunarodno priznate, teritorijalno cjelovite Republike Hrvatske, Družba "Braće hrvatskoga zmaja", Drugo izdanje, Zagreb, 2017.

19. Vukas, B., ml., Hrvatska državnost - pravnopovijesne prosudbe, Pravni fakultet Sveučilišta u Rijeci, Rijeka, 2017.

20. Vukas, B., ml., Pravnopovijesne reference u ustavnim preambulama država srednje i jugoistočne Europe u postkomunističkom razdoblju, Zbornik Pravnog fakulteta u Zagrebu, vol. 63, br. 5 i 6, Zagreb, 2013., str. 1233.-1255.

21. Vukas, B., ml., Zasjedanje prvog višestranačkog hrvatskog sabora (30. svibanj 1990.) - početni impuls dugog putovanja Republike Hrvatske prema Europskoj uniji, u: Zbornik radova Bosna i Hercegovina i euroatlantske integracije - Trenutni izazovi i perspektive, Bihać, 7. i 8. svibnja, 2014., god. II., br. 2, tom I., str. 183.-218.

\section{POPIS PROPISA, AKATA I SUDSKIH ODLUKA}

1. Odluka da se pristupi raspravi o promjeni Ustava SR Hrvatske, Narodne novine, broj 28/1990.

2. Odluka Hrvatskog sabora, Narodne novine, broj 53/1991. 
3. Odluka o proglašenju Amandmana LIV. do LXIII. na Ustav Socijalističke Republike Hrvatske, Narodne novine, broj 7/1990.

4. Odluka o proglašenju Amandmana LXIV. do LXXV. na Ustav SR Hrvatske, Narodne novine, broj 31/1990.

5. Odluka o stavljanju na javnu raspravu Nacrta amandmana LXIV. do LXXII. na Ustav SR Hrvatske, Narodne novine, broj 28/1990.

6. Odluka U-I-3597/2010 i dr. od 29. srpnja 2011., Narodne novine, broj 93/2011.

7. Prijedlog Predsjedništva Socijalističke Republike Hrvatske Predsjedniku Sabora SRH, klasa 01202/90-02/03, Ur. broj: 71201-90-1, od 21. lipnja 1990.

8. Promjena Ustava RH, Narodne novine, broj 76/2010.

9. Ustav SR Hrvatske, Narodne novine, broj 8/1974.

10. Ustavna odluka o suverenosti i samostalnosti Republike Hrvatske te Deklaracija o uspostavi samostalne i suverene Republike Hrvatske, Narodne novine, broj 31/1991.

11. Ustavni zakon o izmjenama i dopunama Ustavnog zakona o pravima nacionalnih manjina, Narodne novine, broj 80/2010.

12. Ustavni zakon za provedbu amandmana LXIV. do LXXIV. na Ustav Socijalističke Republike Hrvatske, Narodne novine, broj 31/1990.

\section{MREŽNI IZVORI}

1. Bohutinski, J., Novi ustroj Hrvatske: treba nam 5 regija i 100 gradova i općina, u: Večernji list, https://www.vecernji.hr/vijesti/novi-ustroj-hrvatske-treba-nam-pet-regija-i-100-gradova-i-opcina-1399506, 4. svibnja 2020. Pristupljeno 5. svibnja 2020.

2. Emisija TV kalendar Hrvatske radiotelevizije od 25. srpnja 2014., https://www.youtube.com/watch?v=cn9MY2HNJwo. Pristupljeno 20. ožujka 2020.

\section{OSTALO}

1. Intervju prof. Ivan Koprić, Večernji list, prilog Obzor, od 25. travnja 2020.

2. Izvješća Hrvatskog sabora, br. 1, 5. VII. 1990.

3. Izvješća Hrvatskog sabora, br. 2, 9. VIII. 1990.

4. Izvješća Hrvatskog sabora, br. 3, 9. VIII. 1990. 


\section{NEW CONCEPTS OF STATE SOVEREIGNTY AND ORGANIZATION OF GOVERNMENT IN THE JULY CONSTITUTIONAL AMENDMENTS OF 1990 - ON THE THIRTIETH ANNIVERSARY OF THE CONSTITUTION OF THE REPUBLIC OF CROATIA}

\section{Summary}

In the year marking three decades since the adoption of the Christmas Constitution, the importance of constitutional amendments promulgated by the Croatian Parliament at the end of July 1990, which together with the February Constitution from the time of the still existing Socialist Parliament form the basic preconditions for initial democratization of the Croatian constitutional system. From a legal-historical and constitutional point of view, the authors consider this issue important for the modern Croatian state. Traditional Croatian historiography analyzes these amendments exclusively in their substantive sense of regulating the new state coat of arms, the flag and abolishing the socialist attributes. Although the amendments are normatively not numerous, their meaning is much broader. At the heart of this analysis lie the issues of a new understanding of state sovereignty and reform interventions in state organization. The authors analyze the relevant provisions through the original records of parliamentary debates. They first point to the basic trends of constitutional changes comprised in the July amendments, referring primarily to the identity level, and then they point to the strengthening of state sovereignty and changes in the direction of developing the features of modern parliamentary democracies. The planned reorganization of the executive-administrative power is especially considered here. At the end, the feed back of the July constitutional amendments and the beginning of work on the new Constitution of the Republic of Croatia are presented.

Keywords: July amendments, February amendments, state sovereignty, private property, Constitution of the Socialist Republic of Croatia, Constitution of the Republic of Croatia

\section{(c) (1) (3)}

This work is licensed under a Creative Commons

Attribution-NonCommercial 4.0 International License.

\footnotetext{
Sanja Barić, PhD, full professor, Faculty of Law, University of Rijeka, Hahlić 6, 51000 Rijeka. E-mail address: sbaric@pravri.hr. ORCID: https://orcid.org/0000-0001-6496-9062.

** Budislav Vukas, Jr., PhD, full professor, Faculty of Law, University of Rijeka, Hahlić 6, 51000 Rijeka. E-mail address: bvukas@ pravri.hr. ORCID: https://orcid.org/0000-0003-0976-9169.
} 